\title{
Silicon Mitigates Adverse Effects of Drought Stress in Wheat (Triticum aestivum L.) Seedlings
}

\author{
Urszula Sienkiewicz-Cholewa $^{1}$, Elżbieta Sacała ${ }^{2 *}$, Magdalena Dziągwa-Becker ${ }^{1}$ \\ ${ }^{1}$ Institute of Soil Science and Plant Cultivation - State Research Institute in Puławy \\ Department of Weed Science and Tillage Systems in Wrocław, Poland \\ ${ }^{2}$ Wrocław University of Environmental and Life Sciences, Department of Plant Nutrition, Wrocław, Poland
}

Received: 20 July 2020

Accepted: 20 January 2021

\begin{abstract}
The study aimed to examine the effect of silicon on spring wheat subjected to drought stress. The experiment was conducted in hydroponic conditions on 10-day old wheat seedlings. Drought stress was induced by polyethylene glycol (PEG 6000) at the concentration of $10 \%$ and $15 \%$ added to nutrient medium. Silicon was used in the form of silicic acid $\left(\mathrm{H}_{4} \mathrm{SiO}_{4}\right)$ at the doses of 1.0 and $1.5 \mathrm{mM}$. Silicon evidently improved growth of all plants. Under stress conditions silicon significantly increased concentration of photosynthetic pigments and lowered malondialdehyde content in leaves. Silicon also had a positive effect on nitrate supply in leaves. Applying silicon, to some extent influenced proline concentration in leaves and soluble carbohydrates content in roots.

Concluding, the application of silicic acid improves growth of wheat seedlings and effectively alleviates the negative effects caused by drought stress.
\end{abstract}

Keywords: nitrate, proline, silicic acid, water stress, lipid peroxidation

\section{Introduction}

Water is an environmental factor governing yield size and its quality of all plants. In many regions of the world, water deficit inhibits seeds germination, causes the delayed and irregular plant emergence and weak growth of seedling. All vital processes in plants are related to water, hence its deficit brings about detrimental changes in plant metabolism and ultimately in plant growth and development. In the conditions of water shortage, plant water management becomes disturbed, stomata are closing and transpiration is

*e-mail: elzbieta.sacala@upwr.edu.pl reduced. Due to high osmotic pressure in the soil, plants suffer from dehydration or even water efflux from plant cells [1]. As a secondary effect, in plant cells may appear oxidative stress. This stress results from over generation of reactive oxygen species that lead to many nonspecific oxidative reactions, including lipids oxidation and increasing membrane permeability. Malondialdehyde (MDA) is one of the products of peroxidation and degradation of plasma membranes and is often used as an indicator of the oxidative damage in cells are very important. In plants are triggered defense mechanisms that help them to survive various stresses. Among them the biosynthesis and accumulation of protective organic compounds in cells. These osmoprotectants (osmolytes) are responsible for osmotic adjustment, turgor maintenance, stabilization of 
proteins and cell structures, removal of reactive forms of oxygen [2, 3]. Very important osmoprotectants include amino acids, particularly proline, and simple sugars and their derivatives. Proline, a protein amino acid, is a major osmoprotectant accumulating in a variety of plant species under different environmental stresses. However, the role of proline, regarded as a component of plant antioxidative system and the osmotic adjustment, seems to be ambiguous. Some researchers question the osmoregulatory role of this compound [4].

To ameliorate negative effects caused by various stress factors different solutions are used. Among them, very important is a proper mineral nutrition using not only conventional essential nutrients but also non-essential but beneficial elements. Silicon is one of examples of such elements, although its role and mechanism of action are not fully understood. Numerous studies show that application of silicon enhances growth, yield and crop quality, photosynthesis, nitrogen fixation, particularly in plants exposed to different abiotic and biotic stresses [5-7]. The experiments of Kaya et al. [8] on maize seedlings revealed that addition of $\mathrm{Si}$ (1 and $2 \mathrm{mM}$ ) improved water-stress tolerance of plants by enhancing relative water content, dry mass of shoots, chlorophyll concentration and reduction of mineral disturbance. Also other studies describe a beneficial role of silicon in plants exposed to water stress and suggest that Si application may be an effective approach to improve growth in these conditions [9-11].

Silicon in the soil solution occurs mainly as mono silicic acid $\left(\mathrm{H}_{4} \mathrm{SiO}_{4}\right)$ and only in this form is available to plants. Absorption of silicic acid takes place at the lateral roots and is performed actively using specific transporters in monocotyledons, such as wheat, sugarcane, rice and barley, and passively using diffusion in dicotyledonous plants. The absorbed $\mathrm{H}_{4} \mathrm{SiO}_{4}$ is deposited mainly in leaf epidermal cells and become condensed into a hard immobile polymerized silica gel $\mathrm{SiO}_{2} \cdot \mathrm{nH}_{2} \mathrm{O}$. Silicon layer in cell walls increases their mechanical strength, reduces transpiration and lead to

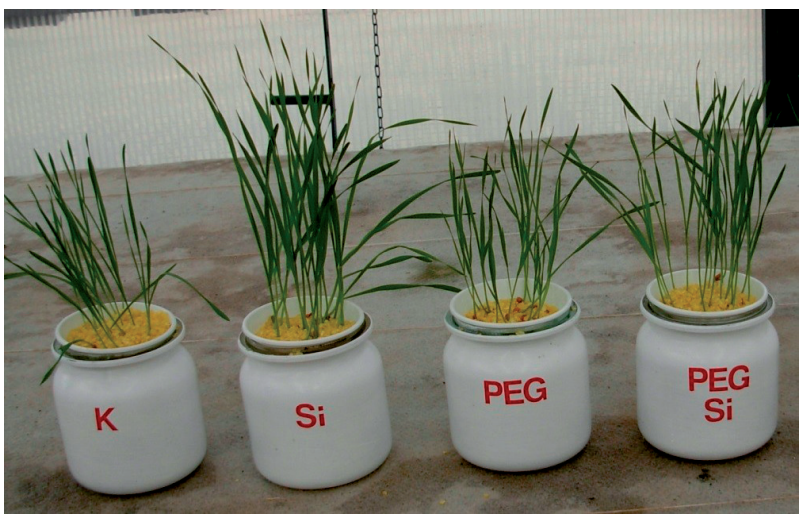

Fig. 1. The influence of mild drought stress (10\% PEG) and silicic acid $\left(1.0 \mathrm{mM} \mathrm{H}_{4} \mathrm{SiO}_{4}\right)$ on 10-day old wheat seedlings (K - Control). Photo taken by U. Sienkiewicz-Cholewa. the use of water by plants more effectively [5, 8-12]. Some authors point to the fact that silicon can prevent degradation of cell membranes structure and functions, as well as it can act as osmolytes regulator in plant cells. However, understanding of the role of $\mathrm{Si}$ in abiotic stress resistance is relatively limited, many issues are still open and new important questions are emerging [13].

The aim of this study was to evaluate the effect of silicon on growth and some biochemical parameters in wheat grown under two levels of drought stress. Silicon was added to a nutrient medium in the form of silicic acid and for this reason obtained results are solely connected with the added silicon. In most experiments researchers use silicates (sodium or potassium) as a source of this element.

\section{Materials and Methods}

\section{Plant Material and Treatments}

The experiments were conducted in the greenhouse of Institute of Soil Science and Plant Cultivation in Wroclaw (Poland), in 2018. Plants were cultivated in the hydroponic cultures in nutrient solution containing (mM): $3 \mathrm{Ca}\left(\mathrm{NO}_{3}\right)_{2} 4 \mathrm{H}_{2} \mathrm{O}, 2 \mathrm{KNO}_{3}, 1 \mathrm{MgSO}_{4} 7 \mathrm{H}_{2} \mathrm{O}$, $1 \mathrm{KH}_{2} \mathrm{PO}_{4}, 0,2$ Fe-EDTA and microelements. The $\mathrm{pH}$ of the solution was adjusted to 6.0. After germination, eighteen uniform germinated grains of spring wheat (Triticum aestivum L.) were transferred into hydroponics and were grown for 10 days. The experiment was carried out at the temperature range of $15-25^{\circ} \mathrm{C}$, and humidity $60-70 \%$. Drought stress was induced by polyethylene glycol (PEG 6000) added to the nutrient solution. Silicon applied in the form of silicic acid was dissolved in water and placed in a ultrasonic bath for 2 hours to obtain stable colloidal system.

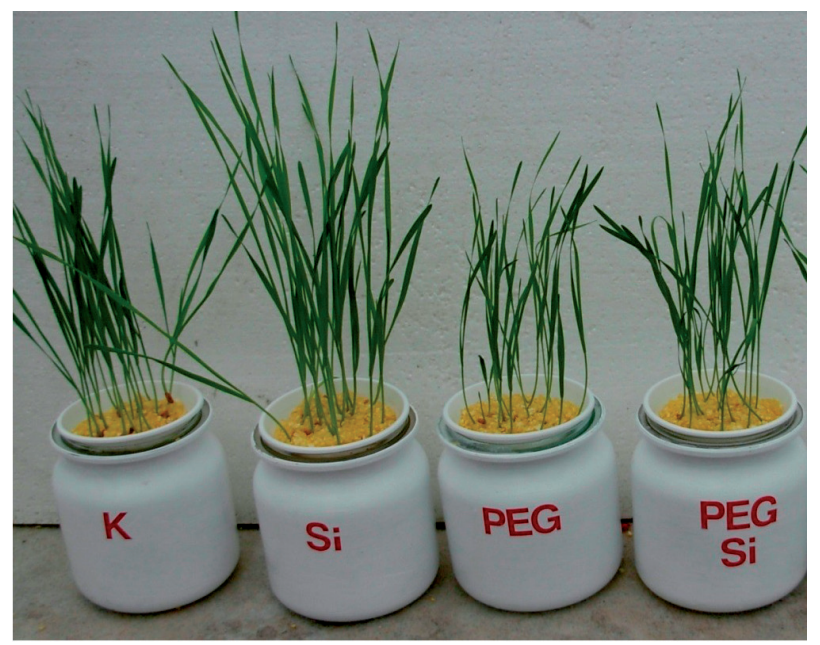

Fig. 2. The influence of severe drought stress (15\% PEG) and silicic acid $\left(1.5 \mathrm{mM} \mathrm{H}_{4} \mathrm{SiO}_{4}\right)$ on 10-day old wheat seedlings ( $\mathrm{K}$ - Control). Photo taken by U. Sienkiewicz-Cholewa. 
The concentrations of silicic acid and PEG were selected on the basis of preliminary tests.

The experimental design consisted of following treatments:

$1 /$ the control (without PEG and $\mathrm{H}_{4} \mathrm{SiO}_{4}$ added),

2/ $1.0 \mathrm{mM} \mathrm{H}_{4} \mathrm{SiO}_{4}$ added,

3/ $10 \%$ PEG added,

4/ $10 \%$ PEG + $1.0 \mathrm{mM} \mathrm{H}_{4} \mathrm{SiO}_{4}$ added.

5/ $1.5 \mathrm{mM} \mathrm{H}_{4} \mathrm{SiO}_{4}$ added,

6/ $15 \%$ PEG added,

7/ $15 \% \mathrm{PEG}+1.5 \mathrm{mM} \mathrm{H}_{4} \mathrm{SiO}_{4}$ added.

There were six replications of each treatment.

\section{Determination of Growth Parameters and Photosynthetic Pigments}

After 10 days of cultivation (adequate period to observe visible symptoms of drought stress and expected positive effects of silicon), plants were harvested and separated into roots and shoots and their lengths and fresh weights were measured. Photosynthetic pigments were extracted with $80 \%$ acetone. The absorbance of the obtained extracts was recorded at 470,647, and $663 \mathrm{~nm}$ and the concentrations of total chlorophyll (chlorophyll $\mathrm{a}+$ chlorophyll b) and carotenoids were calculated using Lichtenthaler [14] equations.

\section{Determination of Malondialdehyde (MDA), Soluble Carbohydrates and Nitrate}

The concentration of MDA was determined by the thiobarbituric acid test. Leaves sample was homogenized in an ice bath with $5.0 \mathrm{~mL}$ of $0.1 \%(\mathrm{w} / \mathrm{v})$ trichloroacetic acid. After centrifugation (12000 g, $15 \mathrm{~min}$ at $4^{\circ} \mathrm{C}$ ) in obtained supernatant MDA concentration was determined according to the method of Heath and Packer [15]. The water-soluble carbohydrates and nitrate were extracted with distilled water at $100^{\circ} \mathrm{C}$ for $30 \mathrm{~min}$ and then were determined spectrophotometrically, sugar according to by the Nelson method [16], and nitrate according to Cataldo et al. [17].

\section{Determination of Proline}

Free amino acids were extracted according to the method by Dziągwa-Becker et al. [18]. The fresh plant material was treated with liquid nitrogen and extracted with LC-MS grade water for $2 \mathrm{~min}$. Homogenates were centrifuged and obtained supernatants were used for amino acid determination. The EZ:faast( $\left.{ }^{\mathrm{TM}}\right)$ Free Amino Acid kit was used and the samples were analysed by LC-MS/MS chromatography using a Shimadzu Prominence system.

\section{Statistical Analysis}

The data for all parameters were statistically analysed using the variance analysis and, evaluation of significance of the mean values between treatments was done through Tukey's test $(\mathrm{P}<0.05)$.

\section{Results and Discussion}

The experiments showed that the drought stress applied at both intensities (10 and 15\% PEG) caused a significant decrease in growth of roots and shoots of wheat seedlings and the observed reduction increased with a rise in stress severity (Figs 3,4). The reduction in length and fresh weight of plant organs ranged from $25 \%$ to $45 \%$ in comparison to control plants. Applying silicon considerably improved the growth of wheat, and

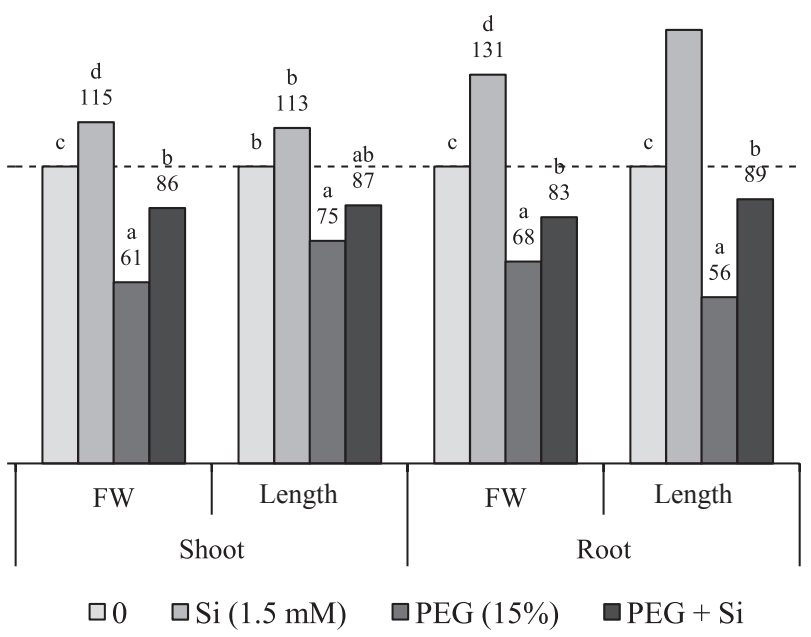

Fig. 4. The influence of severe drought stress (15\% PEG) and silicic acid $\left(1.5 \mathrm{mM} \mathrm{H}_{4} \mathrm{SiO}_{4}\right)$ on growth of 10-day old wheat seedlings. Fresh weight (FW) and length of shoots and roots. Control treatment was taken as a $100 \%$. Values marked by the same letter do not significantly differ. 
Table 1. The effect of drought stress and silicic acid on photosynthetic pigment concentration and MDA and proline content in leaves of 10-day old wheat seedlings. Values marked by the same letter do not significantly differ.

\begin{tabular}{|c|c|c|c|c|}
\hline Treatments & $\begin{array}{c}\text { Total chlorophyll } \\
\left(\mathrm{mg} \mathrm{g}^{-1} \mathrm{FW}\right)\end{array}$ & $\begin{array}{c}\text { Carotenoids } \\
\left(\mathrm{mg} \mathrm{g}^{-1} \mathrm{FW}\right)\end{array}$ & $\begin{array}{c}\text { Proline } \\
\left(\mu \mathrm{g} \mathrm{g}^{-1} \mathrm{FW}\right)\end{array}$ & $\begin{array}{c}\text { MDA } \\
\left(\mathrm{nmol} \mathrm{g} \mathrm{FW}^{-1} \mathrm{FW}\right.\end{array}$ \\
\hline Control & $1.85^{\mathrm{b}}$ & $0.25^{\mathrm{b}}$ & $29.50^{\mathrm{a}}$ & $12.0^{\mathrm{a}}$ \\
\hline $1 \mathrm{mM} \mathrm{Si}$ & $1.91^{\mathrm{b}}$ & $0.28^{\mathrm{b}}$ & $28.75^{\mathrm{a}}$ & $11.7^{\mathrm{a}}$ \\
\hline $10 \%$ PEG & $1.50^{\mathrm{a}}$ & $0.26^{\mathrm{b}}$ & $42.50^{\mathrm{bc}}$ & $16.4^{\mathrm{c}}$ \\
\hline $10 \%$ PEG $+1 \mathrm{mM} \mathrm{Si}$ & $1.81^{\mathrm{b}}$ & $0.25^{\mathrm{b}}$ & $37.50^{\mathrm{b}}$ & $15.0^{\mathrm{bc}}$ \\
\hline $1.5 \mathrm{mM} \mathrm{Si}$ & $2.12^{\mathrm{c}}$ & $0.25^{\mathrm{b}}$ & $28.00^{\mathrm{a}}$ & $13.0^{\mathrm{ab}}$ \\
\hline $15 \%$ PEG & $1.32^{\mathrm{a}}$ & $0.20^{\mathrm{a}}$ & $52.50^{\mathrm{d}}$ & $18.5^{\mathrm{d}}$ \\
\hline $15 \%$ PEG $+1.5 \mathrm{mM} \mathrm{Si}$ & $1.84^{\mathrm{b}}$ & $0.25^{\mathrm{b}}$ & $36.25^{\mathrm{b}}$ & $14.2^{\mathrm{b}}$ \\
\hline
\end{tabular}

the greatest changes were observed in the shoot fresh weight and root length of wheat grown at the higher PEG concentration. The increase was $25 \%$ and $33 \%$ for biomass and length, respectively (Fig. 3, 4). There are numerous reports that confirm a positive impact of exogenously used silicon on growth of plants under stress conditions [9, 19, 20,21].

Drought stress caused a significant reduction in total chlorophyll content $(\mathrm{Chl} \mathrm{a}+\mathrm{Chl} \mathrm{b})$ and at 15\% PEG its concentration decreased by nearly $30 \%$ compared to the control plants (Table 1). Adding silicic acid to the nutrient medium augmented chlorophyll concentration to the value observed in the control plants. Carotenoids content was not lowered under mild water stress $(10 \%$ PEG) but decreased considerably under stronger stress (15\% PEG). And in this case, applying silicic acid considerably increased their concentration. Our results are in line with some other reports indicating that silicon may positively influence chlorophyll accumulation in plants exposed to water stress [10,22].

The water stress resulted in a marked increase in a concentration of MDA that had augmented with increasing drought stress (Table 1). The mild (10\% PEG) and sever (15\% PEG) drought stresses caused $37 \%$ and $54 \%$ increase in MDA content, respectively, indicating that oxidative damages occurs. The presence of silicic acid in the nutrient medium significantly decreased this stress parameter. Different stress factors cause oxidative stress, that is manifested by increased MDA content $[23,24]$. Its concentration may be used as an indicator of oxidative damages. The obtained values of this parameter show that oxidative damages in wheat cells are at moderate level and silicon mitigates this effect. Other researchers have also reported a positive role of silicon in counteraction of oxidative disruptions $[21,23,24]$. However, there are also reports that have not found this beneficial effect [25].

To uptake and transport water under drought conditions plants have to osmotically adjust their cells. To do that plants synthesize and accumulate some organic compounds so-called osmolytes or osmoprotectants. Among the osmolytes, proline is very important and fulfils multiple functions including osmotic adjustment, radical scavenge, electron sink, stabilisation of macromolecules, membranes and a cell wall [26]. Our results showed that drought stress caused a significant increase in proline content in leaves of wheat, and its concentration increased with the severity of stress (Table 1). PEG at concentration of $15 \%$ caused a $78 \%$ increase compared to the control plants, and applying silicon decreased this increment. However, despite this reduction the proline content was maintained

Table 2. The effect of drought stress and silicic acid on soluble carbohydrates and nitrate concentration in shoots and roots of 10-day old wheat seedlings. Values marked by the same letter do not significantly differ.

\begin{tabular}{|c|c|c|c|c|}
\hline \multirow{2}{*}{ Treatments } & \multicolumn{2}{|c|}{ Soluble carbohydrates $\left(\mathrm{mg} \mathrm{g}^{-1} \mathrm{DW}\right)$} & \multicolumn{2}{|c|}{ Nitrate $\left(\mathrm{NO}_{3}{ }^{-}\right)\left(\mu \mathrm{mol} \mathrm{g}^{-1} \mathrm{DW}\right)$} \\
\cline { 2 - 5 } & Shoots & Roots & Shoots & \multicolumn{2}{c|}{ Roots } \\
\hline Control & $14.3^{\mathrm{a}}$ & $18.5^{\mathrm{b}}$ & $1039^{\mathrm{c}}$ & $861^{\mathrm{b}}$ \\
\hline $1 \mathrm{mM} \mathrm{Si}$ & $12.9^{\mathrm{a}}$ & $11.3^{\mathrm{a}}$ & $1554^{\mathrm{d}}$ & $847^{\mathrm{b}}$ \\
\hline $10 \%$ PEG & $25.0^{\mathrm{b}}$ & $16.5^{\mathrm{b}}$ & $593^{\mathrm{ab}}$ & $512^{\mathrm{a}}$ \\
\hline $10 \%$ PEG + $1 \mathrm{mM} \mathrm{Si}$ & $22.8^{\mathrm{b}}$ & $14.6^{\mathrm{ab}}$ & $922^{\mathrm{c}}$ & $532^{\mathrm{a}}$ \\
\hline $1.5 \mathrm{mM} \mathrm{Si}$ & $13.4^{\mathrm{a}}$ & $14.5^{\mathrm{a}}$ & $1115^{\mathrm{c}}$ & $830^{\mathrm{b}}$ \\
\hline $15 \%$ PEG & $26.9^{\mathrm{bc}}$ & $22.6^{\mathrm{c}}$ & $4^{\mathrm{c}}$ & $414^{\mathrm{a}}$ \\
\hline $15 \%$ PEG + $1.5 \mathrm{mM} \mathrm{Si}$ & $28.2^{\mathrm{c}}$ & $11.6^{\mathrm{a}}$ & $621^{\mathrm{b}}$ & $476^{\mathrm{a}}$ \\
\hline
\end{tabular}


at a level markedly higher than in control plants. Jafari et al. [27] found a dramatic increase in proline content in cucumber shoots during osmotic stress (15\% PEG). The enrichment of a solution with silicon $(1.5 \mathrm{mM})$ resulted in a decreased accumulation of this amino acid by as many as $40 \%$. Similar results were obtained in the case of soybean - the decrease numbered $35 \%$ [28]. In the light of our results and literature data we suggest that in wheat seedlings the osmoregulatory role of proline is limited, but alternatively may participate in the protection of cell components.

Similarly to proline, soluble sugars were also accumulated in wheat shoots under drought stress (Table 2). The recorded concentration was nearly two fold higher than in the control plants. Applying silicon did not affect significantly this parameter. Roots reaction was different. Mild drought stress $(10 \%$ PEG) did not affect this parameter, whereas stronger stress resulted in a $22 \%$ increment in the soluble sugars content. It is worth to note that applied silicic acid caused a considerable reduction in sugars concentration and their level was $47 \%$ lower than in the control plants. Accumulation of soluble sugars as a result of different PEG concentration (10, 20, 30 and $40 \%$ ) was found by Mohammadkhani and Heidari [29] in two maize cultivars. The concentration of carbohydrates increased from 1.2 to 1.9 times in roots and shoots when the studied varieties were subjected to drought stress. Also Sacała and Durbajło [30] found that drought stress $(10 \%$ PEG) caused a $23 \%$ increase in soluble carbohydrates in maize leaves. In roots statistically significant change was not observed. Our results showed that in wheat roots a marked increase in the content of soluble carbohydrates took place only under more severe drought stress (15\% PEG). A primary source of sugars is photosynthesis, hence leaves can respond fast to relatively low water stress, while changes in roots occurred under more severe water stress. Drought-induced accumulation of soluble sugars in plant tissues, may be concerned as a positive effect, important for the osmotic adjustment in plants. Contrary results were presented by Karmollachaab and Gharineh [20] who stated that water deficit reduces soluble sugar concentrations in wheat leaves. However, applying silicon increased carbohydrates level by $22 \%$ comparing to control plants.

Drought stress very often disturbs uptake of essential nutrients. We demonstrated that nitrate concentration in wheat organ was dramatically reduced. Nitrate concentration decreased approximately two times compared to the control plants (Table 2). Decrease in nitrate content under water stress was also observed in other plants [30, 31]. Alternatively, applying silicon noticeably improved nitrate supply in wheat shoots, and the increase was 50\% comparing to plants without silicic acid added. Root reaction was different then this observed in shoots and silicon supplementation did not modify nitrate content nor in plants grown in optimal conditions nor in stress conditions.
In general, silicon plays an important role in processes associated with photosynthesis, osmoregulation, antioxidative defense and nitrate distribution in wheat seedlings.

\section{Conclusions}

The presented results indicate that silicon has a great impact on wheat growth and functioning under the optimal and stress conditions. The positive impact of silicon on wheat seedlings grown under drought stress results from three effects that were found: (1) increase in chlorophyll concentration, (2) reduction in membranes lipid peroxidation, (3) better supply of nitrate in wheat leaves. Application of silicic acid to the root medium may be an effective strategy to improve the growth and functioning of wheat seedlings exposed to drought.

\section{References}

1. BASU S., RAMEGOWDA V., KUMAR A., PEREIRA A. Plant adaptation to drought stress. F1000Research. 5, 1554, 2016.

2. BLUM A. Osmotic adjustment is a prime drought stress adaptive engine in support of plant production. Plant Cell Environ. 40 (1), 4, 2016.

3. ATKINSON N.J., URWIN P.E. The interaction of plant biotic and abiotic stresses: from genes to the field. J. Exp. Bot. 63 (10), 3523, 2012.

4. HAYAT S., HAYAT Q., ALYEMENI M.N., WANI A.S., PICHTEL J., AHMAD A. Role of proline under changing environments. A review. Plant Signal. Behav. 7 (11), 1456, 2012.

5. RIZWAN M., ALI S., IBRAHIM M., FARID M., ADREES M., BHARWANA S.A., ZIA-UR-REHMAN M., QAYYUM M., ABBAS F. Mechanisms of siliconmediated alleviation of drought and salt stress in plants: a review. Environ. Sci. Pollut. Res. 22, 15416, 2015.

6. MA J.F., YAMAYI N. A cooperative system of silicon transport in plants. Trends Plant Sci. 20(7), 435, 2015.

7. SACAŁA E. Role of silicon in plant resistance to water stress. J. Elem. 14 (3), 619, 2009.

8. KAYA C., TUNA L., HOGGS D. Effect of silicon on plant growth and mineral nutrition of maize grown under water-stress conditions. J. Plant Nutr. 29 (8), 1469, 2006. doi: $10.1080 / 01904160600837238$.

9. AFEF O., SOUROUR A., ZOUBEIR C., MOUNIR R., HAJER S.A., MONGI B.Y. Silicon alleviates adverse effect of drought stress induced by polyethylene glycol (PEG 8000) on seed germination and seedling growth of durum wheat varieties. Int. J. Curr. Res. 8 (11), 40847, 2016.

10. AHMED M., ASIF M., HASSAN, F. Augmenting drought tolerance in sorghum by silicon nutrition. Acta Physiol. Plant. 36 (2), 473, 2014.

11. PEREIRA T.S., DA SILVA LOBATO A.K., TAN D.K.Y., DA COSTA D.V., UCHOA E.B., NASCIMENTO FERREIRA R., SILVA GUEDES E.M. Positive interference of silicon on water relations, nitrogen metabolism, and osmotic adjustment in two pepper 
(Capsicum annuum) cultivars under water deficit. Aust. J. Crop Sci. 7, 1064, 2013.

12. COSKUN D., BRITTO D.T., HUYNH W.Q., KRONZUCKER H.J. The role of silicon in higher plants under salinity and drought stress. Front. Plant Sci. 7, 1072, 2016.

13. TUBANA B.S., BABU T., DATNOFF L.E. A review of silicon in soils and plants and its role in US agriculture: history and future perspectives. Soil Sci. 181 (9/10), 393, 2016.

14. LICHTENTHALER H.K. Chlorophylls and carotenoids: pigments of photosynthetic biomembranes. Methods Enzymol. 148, 350, 1987.

15. HEATH R.L., PACKER L. Photoperoxidation in isolated chloroplasts. I. Kinetics and stoichiometry of fatty acid peroxidation. Arch Biochem. Biophys. 125 (1), 189, 1968.

16. NELSON N. A photometric adaptation of the Somogyi method for the determination of glucose. J. Biol. Chem. 153, 375, 1944.

17. CATALDO D.A., HAROON M., SCHRADER L.E., YOUNGS V.L. Rapid colorimetric determination of nitrate in plant tissue by nitration of salicylic acid. Commun Soil Sci. Plant Anal. 6, 71, 1975.

18. DZIĄGWA-BECKER M., RAMOS J.M.M., TOPOLSKI J., OLESZEK W. Determination of free amino acids in plants by liquid chromatography coupled to tandem mass spectrometry (LC-MS/MS). Anal. Methods. 7, 7574, 2015.

19. DING Y.F., LIANG Y.C., ZHU J., LI Z.J. Effects of silicon on plant growth, photosynthetic parameters and soluble sugar content in leaves of wheat under drought stress. Plant Nutr. Fert. Sci. 13, 471, 2007.

20. KARMOLLACHAAB A., GHARINEH M.H. Effect of silicon application on wheat seedlings growth under waterdeficit stress inducted by polyethylene glycol. Iran Agric. Res. 34 (1), 31, 2015.

21. SIENKIEWICZ-CHOLEWA U., SUMISŁAWSKA J., SACAŁA E., DZIĄGWA BECKER M., KIELOCH R. Influence of silicon on spring wheat seedlings under salt stress. Acta Physiol. Plant. 40, 54, 2018.

22. WANG X.S., HAN J. G. Effects of $\mathrm{NaCl}$ and silicon on ion distribution in the roots, shoots and leaves of two alfalfa cultivars with different salt tolerance. Soil Sci. Plant Nutr. 53 (3), 278, 2007.
23. PEI Z.F., MING D.F., LIU D., WAN G.L., GENG X.X., GONG H.J., ZHOU W.J. Silicon improves the tolerance to water-deficit stress inducted by polyethylene glycol in wheat (Triticum aestivum L.) seedlings. Plant Growth Reg. 29, 106, 2010.

24. XU L., ISLAM F., ALI B., PEI Z., LI J., GHANI M.A., ZHOU W. Silicon and water-deficit stress differentially modulate physiology and ultrastructure in wheat (Triticum aestivum L.). Biotechnol. 7 (4), 273, 2017.

25. SAPRE S.S., VAKHARIA D.N. Silicon inducted physiological and biochemical changes under polyethylene glycol-6000 water deficit stress in wheat seedlings. J. Environ. Biol. 38 (2), 313, 2017.

26. HASANUZZAMAN M., NAHARB K., ANEEA T.I., KHANC M.I.R., FUJITAD M. Silicon-mediated regulation of antioxidant defense and glyoxalase systems confers drought stress tolerance in Brassica napus L. South African J. Bot. 115, 50, 2018.

27. JAFARI S.R., ARVIN S.M.J., KALANTARI K.M. Response of cucumber (Cucumis sativus L.) seedlings to exogenous silicon and silicic acid under osmotic stress. Acta Biol. Szeged. 59 (1), 25, 2015.

28. SHEN X., ZHOU Y., DUAN L., LI Z., ENEJI E., Li J. Silicon effects on photosynthetic and antioxidant parameters of soybean seedlings under drought and ultraviolet-B radiation. J. Plant Physiol. 167, 1248, 2010.

29. MOHAMMADKHANI N., HEIDARI R. Drought-induced accumulation of soluble sugars and proline in two maize variety. World Applied Sci. J. 3 (3), 448, 2008.

30. SACAŁA E., DURBAJŁO W. The effect of sodium silicate on maize growing under stress condition. Przem. Chem. 91 (5), 949, 2012 [In Polish].

31. CORREIA M.J., FONSECA J. AZEDO-SILVA C., DIAS C., DAVID M.M., BARROTE I., OSÓRIO M.L., OSÓRIO J. Effects of water deficit on the activity of nitrate reductase and content of sugars, nitrate and free amino acids in the leaves and roots of sunflower and white lupin plants growing under two nutrient supply regimes. Physiol. Plant. 124 (1), 61, 2015. 